Interfaces

\title{
Adjusting to adversity: The prelude to prosperity
}

\section{Gerhard de Kock \\ Governor of the South African Reserve Bank, P.O. Box 427, Pretoria 0001, Republic of South Africa}

Address delivered by Dr Gerhard de Kock at a banquet in Johannesburg on March 9, 1982, to mark the inauguration of the Barclays Centre for Management Studies.

\section{Predicting the boom of 1980-81}

Two and a half years ago, in October 1979, I had the privilege of addressing the Annual Meeting of Assocom - the Association of Chambers of Commerce - in Bloemfontein. At that time the South African economy found itself in a somewhat sluggish upswing. But the gold price was rising and, in response to a strong world demand, the value of South African exports in general was increasing strongly. It was therefore easy at that time to predict that the balance of payments would show a substantial surplus and that the upswing would gain considerable momentum in the year ahead, and it was to that theme that I devoted most of my address. I ended my talk with the message to Assocom members: 'Prepare to meet thy boom!'

This punch line was, of course, not original, but it went down rather well. It is never easy for sadistic central bankers to amuse hard-boiled businessmen, but on that occasion they actually laughed! Afterwards, however, several members of the audience came up to me and said: 'You don't really believe that the South African economy is going to boom, do you, not with all our political uncertainties?' I replied that I had meant every word and that I was convinced that the upswing would gain considerable momentum in the period immediately ahead. But many of those businessmen just smiled knowingly and said that they understood I had to say things like that in public, but that they didn't share my confidence and optimism.

Well, it is now a matter of history that South Africa did, in fact, experience what was perhaps the most vigorous boom in its history in 1980 and 1981 . Moreover, the upswing which had already commenced at the end of 1977 , continued until the third quarter of 1981 before it reached an upper turning point. And after rising by $8 \%$ in 1980 , the real gross domestic product registered a remarkable further increase of about $4,5 \%$ in 1981 - remarkable because by the end of 1980 virtually all the slack in the economy had been taken up.

\section{Predicting a difficult year for the economy in 1982}

In the course of 1981, however, it became increasingly evident that the economy as a whole, the balance of payments and the exchequer were all being adversely affected by the decline in the gold price and by the world-wide recessionary conditions which had developed in the meantime. As a result of these adverse exogenous factors, the value of some of South Africa's main exports declined. Since our imports were at that stage still rising as a symptom of the overheated domestic economy, the surplus on the current account of the balance of payments of R2,8 billion in 1980 was transformed into a substantial deficit, which in the end amounted to about R4 billion for 1981 as a whole. This resulted in both a decline in our net gold and other foreign reserves, and a substantial depreciation of the rand against other currencies and particularly against the United States dollar. The writing on the wall was therefore clear: one way or another the economy would have to adjust to the new situation. This made it all the more certain that the South African business cycle would move into a downward phase before long.

I underline the significance of these adverse developments in a number of public addresses during 1981, including the chairman's address at the annual meeting of the Reserve Bank in August. In these addresses I stressed the inevitability of balance of payments adjustment and predicted that 1982 was bound to be a difficult year for the South African economy. I therefore fully associated the Reserve Bank with the approach of 'consolidation and adjustment' announced by the Minister of Finance in his Budget speech in August 1981.

Again, some of my business and banking friends told me that they simply did not agree with this view and therefore saw little merit in the 'consolidation and adjustment' approach. They pointed to the general buoyancy of the economy, the high and rising levels of investment and consumption, the strong demand for bank credit, the shortage of skilled labour, the rising imports, the strength shown by share prices on the Stock Exchange, the building boom and so on. And many of them went ahead with their business activities as if nothing had happened. Other countries might have serious economic problems, they conceded, but there was no reason why this should materially affect the South African situation. As late as January 1982 this view was still being propounded in some business circles.

I think the argument has now been settled. It is now generally realized that 1982 is going to be a difficult year for the South African economy. The penny has finally dropped.

There now appears to be general agreement with the summing up of the situation given by the Minister of Finance in the House of Assembly on February 11, 1982 in his Part Appropriation speech. On that occasion he stated: 'The Government is fully aware . . . that the economic situation and short-term prospects have been adversely affected by a number of overseas economic developments in recent months. First and foremost, the price of gold has declined from an average of $\$ 613$ per ounce in 1980 to one of $\$ 460$ per ounce in 1981 and an average so far this year of $\$ 383$ per ounce. (The latest average is $\$ 375$ per ounce.) Secondly, the marked deterioration in the world economic situation during recent months has had an unfavourable impact on the growth of our exports in general. And thirdly, the maintenance of tight money policies and high real rates of interest in the main industrial countries has naturally contributed to higher interest rates and a general tightening of our own financial markets. The South African economy is therefore con- 
fronted by certain short-term problems which, although of a transitional nature, require immediate attention.'

\section{Fiscal and monetary policy in 1981 - a retrospec- tlve view}

At this point the cynic will no doubt ask: 'If the forecasts of the Treasury and the Reserve Bank were as good as you claim they were, why didn't the monetary authorities apply more stringent remedial measures at an earlier stage?' This is a fair question. In retrospect, it is clear that if fiscal and monetary policy erred in 1981, it was not on the side of 'overkill' as some critics claimed at the time, but rather on the side of leniency and expansionism. We tended to pay too much attention to the predictions of some economists that the South African economy would move into a severe recession in 1981 and that the United States and the other main industrial countries would move into an upturn in the second half of that year - predictions which have now been proven wrong.

In an attempt to bring about a 'soft landing', we shielded the domestic economy too much from the adverse effects of the declining gold price and the world recession. We did this, for example, by permitting the rand to depreciate against the United States dollar and most other major currencies, thereby preventing the rand income of exporters from declining as much as their dollar income. The Reserve Bank also borrowed substantial amounts abroad and entered into new gold swop agreements. On the domestic front, the Bank arranged the extension of record amounts of bank advances to the Land Bank, at relatively low rates of interest, to finance the large maize and other crops through the agricultural co-operatives. At one stage the Reserve Bank itself extended credit to the Government and to official extra-budgetary funds. It also continued to perform its function of 'lender of last resort' by granting accommodation to discount houses and other banking institutions at times of financial tightening. Moreover, although it provided such assistance at rising rates of interest, these rates were still low in relation to overseas interest rates and to our own inflation rate. By leaning over backwards in this way to protect the domestic economy in the interests of growth, the monetary authorities probably slowed down the working of the balance of payments adjustment process.

On the more positive side, the Reserve Bank did exercise stricter control over the money supply and permitted financial markets to tighten and interest rates to rise sharply in response to market forces. This policy yielded beneficial results, the full impact of which will only be felt in the coming months. Apart from facilitating the financing of the deficit on the current account of the balance of payments, this more restrictive policy stance contributed to a desirable decline in the seasonally-adjusted annual rate of increase of the broad money supply from $46 \%$ in the first quarter of 1981 to $26 \%$ in the second quarter and $10 \%$ in the third quarter.

Unfortunately, however, as the Minister of Finance pointed out in his Part Appropriation speech last month, monetary policy suffered a temporary setback in the fourth quarter of 1981 as a result of two developments. The first was the financing of the record maize crop and other farming activities through bank credit extended to the Land
Bank - at one stage the total outstanding bank credit to the Land Bank amounted to a record $\mathrm{R} 2,3$ billion. And the second was the temporary increase in the use of bank credit by the government sector to which I have referred. Partly as a result of these developments, the annual rate of increase of the broad money supply rose to $21 \%$ in the fourth quarter of 1981 .

On balance, therefore, monetary and fiscal policy was not yet tight enough in 1981. If the gold price and the world economy had recovered in the second half of 1981 as many experts had predicted, the policies actually applied might well have been vindicated. Unfortunately, however, things moved the other way. The gold price went down, not up; and the main industrial countries did not experience the predicted recovery, but remained in a deep recession. The need for adjustment in the South African economy therefore became greater.

\section{The current policy stance}

As a result of these various developments, the Treasury and the Reserve Bank, as far back as November 1981, decided to take stronger corrective action to curb excess monetary demand.

To begin with, interest rates were permitted to rise further in response to market forces. To this end, the Reserve Bank ceased the practice it had followed temporarily in the third quarter of 1981 of quoting artificial discounts on forward dollars with the aim of compensating for South Africa's relatively low interest rates and encouraging the use of foreign import and export financing. This practice had achieved its desired effect of easing the pressure on the official foreign reserves, but had weakened the restrictive impact of the Bank's domestic monetary policy. The artificial discounts on forward dollars were therefore replaced by more realistic premiums.

This interest rate policy was reinforced by a further increase in bank rate on December 15, 1981, which permitted the clearing banks' prime overdraft rates to rise to $17 \%$. Even more important was the decision to permit the Treasury bill rate to rise above bank rate to realistic market-related levels. In the event, the Treasury bill rate rose from below $12 \%$ in early November to $15,76 \%$ last Friday (March 5, 1982).

A further significant policy change was the abolition, on February 16,1982, of the previously existing direct link between bank rate and prime overdraft rates, which permitted the latter rates to rise in response to market forces to their present realistic levels of 19 and $20 \%$. At the same time, the Reserve Bank discouraged banks and discount houses from excessive recourse to its discount window by applying severe penalty rates, well above bank rate, to all such financial accommodation.

A crucially important step was the decision by the Minister of Finance to advance the date of the introduction of the Part Appropriation Bill to February 11, 1982 and to use that opportunity to increase the general sales tax from $4 \%$ to $5 \%$ and to impose a surcharge of $10 \%$ on imported goods. He also introduced a new method of issuing government stock by way of tender and raised the interest rate on taxfree Treasury bonds.

Since the 1982/83 Budget is due to be introduced in two weeks' time, I shall refrain from making any comments 
on the nature of fiscal policy in the year ahead. What I can say, however, is that under the firm leadership of the Prime Minister, the Minister of Finance and the entire Cabinet, the authorities now have a cohesive package of economic stabilization policies in place which clearly demonstrates their resolve to do whatever is necessary to ensure that the South African economy makes the adjustments required by the adverse external developments of recent months, and makes them in good time.

We are determined to carry the policy of 'consolidation and adjustment' to its logical conclusion. This means exercising tight control over government spending, banking liquidity and the money supply. It also means permitting financial markets to tighten further if necessary and accepting realistic interest rates. The lower average gold price and the other adverse external developments I have outlined are facts of life which cannot be ignored or neutralized by money creation or fiscal manipulation. We can argue about the appropriate methods of adjustment, weighing up their different costs and benefits. But the inevitability of adjustment must be accepted. As the Minister of Finance put it in his Part Appropriation speech, 'we have to face up to the economic and financial realities of the day if we are to preserve the fundamental strength and soundness of our economy, and if we are to place ourselves in a position where we can derive the maximum benefit from a recovery in world economic conditions, a recovery which many believe will set in within the next year or so'.

\section{Policy 'trade-offs'}

Given the inevitability of adjustment in present circumstances, the point needs to be made that in considering the appropriate 'mix' of fiscal and monetary policies in South Arica today, there exists a certain 'trade-off' between high interest rates, high tax rates (or lower government spending) and exchange rate depreciation. As the experience of the past months has shown once again, effective adjustment policies usually include some combination of all three of these 'remedies'. But different 'mixes' are possible. Thus, for example, the more use is made of higher taxes or cuts in government spending, the less need there will be for interest rates to remain high or to rise further. In other words, the more fiscal policy there is in the 'mix', the less reliance has to be placed on monetary policy, and vice versa. Similarly, the greater the extent to which taxes are raised and/or interest rates allowed to rise, the less need there will be for the currency to depreciate in the foreign exchange market. The optimal combination of tax rates, interest rates and spot and forward exchange rates in South Africa, and how to achieve this ideal 'mix', are matters receiving more attention from the monetary authorities in South Africa today than ever before.

\section{Policy priorities}

Finally, a word about policy priorities. The monetary authorities at all times have to seek some reconciliation between the objectives of rapid economic growth, reasonable price stability and balance of payments equilibrium. In South Africa we believe that, in the long run, reasonable price stability is conducive to both optimum economic growth and balance of payments equilibrium, and that these three objectives are therefore compatible. In the short term, however, there can at times be a conflict between them.

During the past year, for example, the authorities have not found it possible to accord as high a priority to the curbing of monetary demand and inflation as they would have wished. Instead, they have been compelled by adverse external developments to seek a compromise between this aim and the objectives of correcting a balance of payments deficit and maintaining a reasonable rate of economic growth. This is evident from the decision to permit the rand to depreciate in the foreign exchange market, as well as from the recent imposition of a surcharge on imports steps which are desirable for balance of payments reasons, but which tend to boost domestic spending and to contribute to higher price levels in the short term.

Such a compromise is still a major policy objective. But the recent adverse overseas developments have narrowed our options, and there is now more emphasis on bringing about the required balance of payments adjustment by curbing monetary demand, even if this has a certain procyclical restraining effect on the domestic economy in the short term. In present circumstances, we must accept the need for, and the consequences of, increased financial discipline, tighter control of the money supply and continued high interest rates. The events of recent weeks and days in the world economy, and particularly in the gold market, have underlined the vital necessity for measures of this kind. There are no 'soft options' or 'quick fixes'. The only answer is to work harder and to live within our means.

\section{Prelude to prosperity}

Looking ahead, the important thing is to maintain a proper perspective. The lower gold price and the stagnant conditions in the world markets for many of our other exports are harsh realities which have to be faced, and the need for further consolidation and adjustment in our economy must be accepted. This year, 1982, is going to be a difficult year and the policy measures now being applied are not going to be popular. But there are no grounds for pessimism as to the medium- and long-term growth prospects for the South African economy. On the contrary, the very purpose of our present stabilization policies is to set the stage for the next economic upswing.

Nobody can be precise about the dates, but it is surely only a matter of time before the United States economy leads the world into a new upward phase of the business cycle and the gold price commences its next upward movement. When that time comes, the South African economy will have cooled down adequately, the volume of imports will consequently have declined sharply, the pressure of excess demand on resources will have eased, and we shall be in a strong position to take full advantage of the world economic recovery and the resultant increase in the demand for our exports. Hence my conviction that adjusting to adversity now is the prelude to new prosperity. 